\title{
In the spiral of mistrust: On the decline of public trust in Czech journalists
}

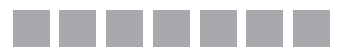 \\ Jaromír Volek \\ Marína Urbániková \\ MASARYK UNIVERSITY, CZECH REPUBLIC
}

DOI: 10.19195/1899-5101.10.2(19).1

\begin{abstract}
This paper analyses the change of public trust in journalists in the Czech Republic and investigates the main characteristics of mistrusting audiences. Comparative analysis based on two representative surveys of the Czech population reveals that public trust in journalists declined by a third between 2004 and 2016. Mistrust is on the rise especially among: (a) socio-economically deprived media consumers (b) with leftist political orientation c) belonging to the youngest cohort. The analysis also indicates a split of the ideal-typical image of a journalist as a highly-educated advocate of socially vulnerable groups, and suggests the return of a perception of journalists as establishment representatives which prevailed during the previous "real socialist" regime.
\end{abstract}

KEYWORDS: Czech journalists, mistrusting audiences, political orientation, trust.

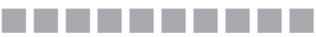

\section{INTRODUCTION}

Having the trust of the audience is of fundamental importance for media and journalists, and in a broader perspective, also for the democracy and stability of social systems. Trust constitutes a key working tool of journalists without which they cannot, in fact, appear in the field and make contacts with their sources. Trust of the audiences is also crucial for the commercial sustainability of the media. Moreover, the media serve as an intermediary between the government and the people, they provide them with information and act as a forum for the views of citizens. The lack of trust in this forum can therefore be a potential threat for democracy. Finally, media and journalists do not only depend on the trust of their audiences, they also play an important role in the process of building trust in other parts of society. Trust is a basis for social cohesion and social order (Gellner, 1990) and it is required as an input condition for functioning of a social system (Luhmann, 1990); without trust, the stability of the social system is at risk. Therefore, erosion of trust in the media and journalists can have far-reaching consequences. 
Paradoxically, it seems that in the times of journalism's greatest technological explosion, public trust as its vital component is on the decline. A number of studies affirm the increasingly skeptical attitude of the public to the until recently accepted journalistic privilege to explicate social reality (Kovach \& Rosenstiel, 2001). This process of weakening trust in the media concerns different media systems with varying intensity. For instance, Gronke and Cook (2007) show that, between 1973 and 2000, the trust of the public in the US media sank more than trust in any other observed professions. According to a recent Gallup Poll (2016), trust and confidence in the media among American public has fallen to the lowest point in the poll's 44-year history, with only $32 \%$ saying they have a great deal or fair amount of trust in the media. Muller (2013) points out that the biggest slump in trust can be detected in countries which, according to the typology of Hallin and Mancini (2004), belong to the North Atlantic/liberal media system. In contrast, quite stable trust prevails in countries with Mediterranean/ polarized pluralistic models and in countries with North and Central Europe/democratic-corporatist models.

In the European Union, trust in the media has been falling systematically in the past eight years in both old EU countries and new ones (Eurobarometer, 2016) ${ }^{1}$. However, the fall in trust in the latter is more distinctive, exceeding $10 \%$. While in $2007,61 \%$ of respondents from both old and new member states tended to trust the media, by 2015 , this number had decreased to $54 \%$ in the case of respondents from old member states and $48 \%$ in the case of respondents from new member states. This suggests that in post-communist countries, public trust is more fragile in comparison with stable Western democracies.

Although a number of recent studies affirm a rising public mistrust in media and journalists, they usually focus on the most developed Euro-American countries. This paper brings unique data showing that this trend also applies to the Czech Republic as a Central European country with a post-communist media model. It compares the level of public trust in journalists in the Czech Republic within the time span of twelve years (2004-2016), and analyzes the main characteristics and structure of mistrusting audiences.

\section{THE RISE AND FALL OF PUBLIC TRUST IN CZECH MEDIA}

According to cultural theories, trust in people and in institutions is a product of accumulated historical experiences (Sztompka, 2000), and it is intergenerationally

1 The author's calculation based on Eurobarometer (2016) results. Trust in media was calculated as an average of trust in TV, radio, and press. Question wording: I would like to ask you a question about how much trust you have in certain institutions. For each of the following institutions [the press, television, radio, the internet], please tell me if you tend to trust it or tend not to trust it? Possible answers: tend to trust; tend not to trust. Old EU members = Austria, Belgium, Denmark, Finland, France, Germany, Greece, Ireland, Italy, Luxembourg, Netherlands, Portugal, Spain, Sweden, United Kingdom. New EU members = Bulgaria, Croatia, Cyprus, Czech Republic, Estonia, Hungary, Latvia, Lithuania, Malta, Poland, Romania, Slovakia, Slovenia. 
transmitted and deeply embedded in society (Mishler \& Rose, 2005). The question of public trust in media and journalists in the Czech Republic has to be therefore considered in a broader context of its history and the transformation of society after the fall of the totalitarian regime (also known under the catchphrase "real socialism") in 1989.

The previous regime, as well as the transformation process of so-called postcommunist societies, are thought to have caused a widespread erosion of trust in Central and Eastern European countries, including the Czech Republic (see for example Mierina, 2011). According to Sztompka (2000), communist societies developed a 'bloc culture' with various traits and characteristics leading to the decay of trust, e.g., the distinction between public sphere (domain of the bad) and private sphere (domain of the good) going hand in hand with the double standards of truth (official and private), or autocratic style of politics with arbitrary policies and unclear criteria of political decisions. Trusting the state and its political institutions, including media and journalists, was seen as naive and stupid, and, on the other hand, trying to beat the system and outwit the authorities was widely recognized as a virtue. Therefore, as put by Rose (1994, p. 18), distrust can be considered as "a pervasive legacy of communist rule".

The fall of the communist regime and the democratic replacement of the old and distrusted regime brought a wave of national unity and solidarity, as well as a revival of public trust. This was only temporary, as the pains of the transformation process with its radical political, economic, and societal changes led to the 'postrevolutionary malaise' or 'the morning after syndrome' (Sztompka, 1992), and with that to a profound collapse of trust (Sztompka, 2000). Rigid social controls were released, old norms have fallen down, and new ones have not yet been developed, and emergence of new life chances generated brutal competition with unclear rules (Sztompka, 2000). However, the consolidation of political democracy, economic growth and the inclusion into Western alliances, together with generational turnover, initiated a gradual revival of trust (Sztompka, 2000).

Naturally, Czech media and journalists did not stand unaffected by this historical development. After World War II, the Czech journalistic field was formed under the direct influence of the so-called Soviet theory of journalism, which saw journalism primarily as a propaganda activity aimed at educating citizens to be loyal to the communist establishment and the Communist Party as the leading force, which has the right "when journalist activity does not correspond to its demands, to strip him of the right to speak on its behalf, or may choose other means to influence him" (Tepljuk, 1989). Although there are no data on public trust in journalists from the pre-1989 period, it can be assumed that especially in the last decade before the transition it was at a low level. The Czech public, for instance, projected this kind of mistrust into a saying popular at the end of the 1980s: 'Czech TV lies like Rudé právo prints'.

${ }^{2}$ Red Justice or Red Truth was the official newspaper of the Communist Party of Czechoslovakia. Czech television broadcasting was controlled by the state under the old regime. The slogan plays on a Czech idiom: to lie like they print (= to lie extensively/obviously). 
After 1989, public trust in journalists and media has been at least partially restored, only to experience a decline starting after the onset of the economic crisis in 2008. As a proxy indicator for missing data on public trust before 1995, a continual measurement of prestige of the journalistic profession among the Czech public starting in 1990 can be used. It shows a significant increase in perceived prestige in the years shortly after the revolution and relatively stable values until the arrival of the economic crisis (Figure 1).

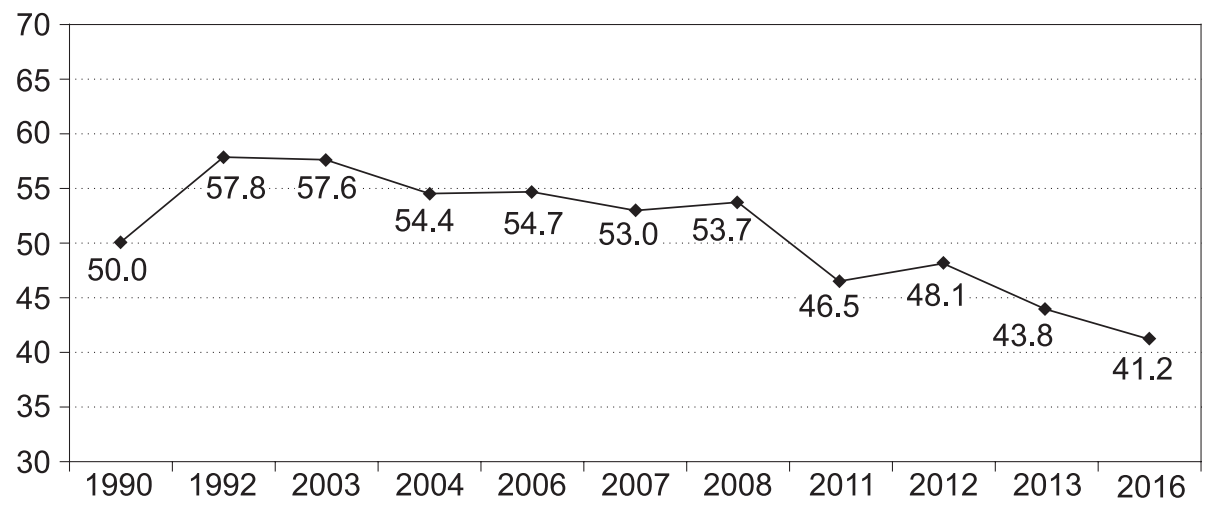

Figure 1. Prestige of journalism as a profession in the Czech Republic, 1990-2016 (in \%)

Source: Czech Social Science Data Archive of the Czech Institute of Sociology; the authors' calculation.

Legend: The data in the figure represent the average score of prestige on a scale from $1=$ the lowest prestige to $99=$ the highest prestige.

The regular assessment of public trust in media started in 1995. As demonstrated in Figure 2, the first noticeable drop in public trust was distinguishable as early as in 2001-2002. It increased in 2007, and accelerated in 2009 when the first tangible impact of the economic crisis appeared; the progression of mistrust affected all the media types.

Although there is a continual measurement of public trust in media, it is necessary to distinguish between public trust in media and in journalists, since trust in institutions can differ from trust in individuals (see, e.g., Newman et al., 2016). Investigation of public trust in journalists is still missing in the Czech Republic. This paper aims to fill in the gap and report on the change of trust in journalists among the Czech population, as well as on the structure and main characteristics of mistrusting audiences.

\section{PUBLIC TRUST IN NEWS MEDIA AND JOURNALISTS: LITERATURE REVIEW}

The research on public trust in the journalistic field monitors two main topics: a) analysis of trust in media institutions, usually conducted through a comparison of individual media types, and b) less frequent research on the trust in journalists as a socio-professional group. 


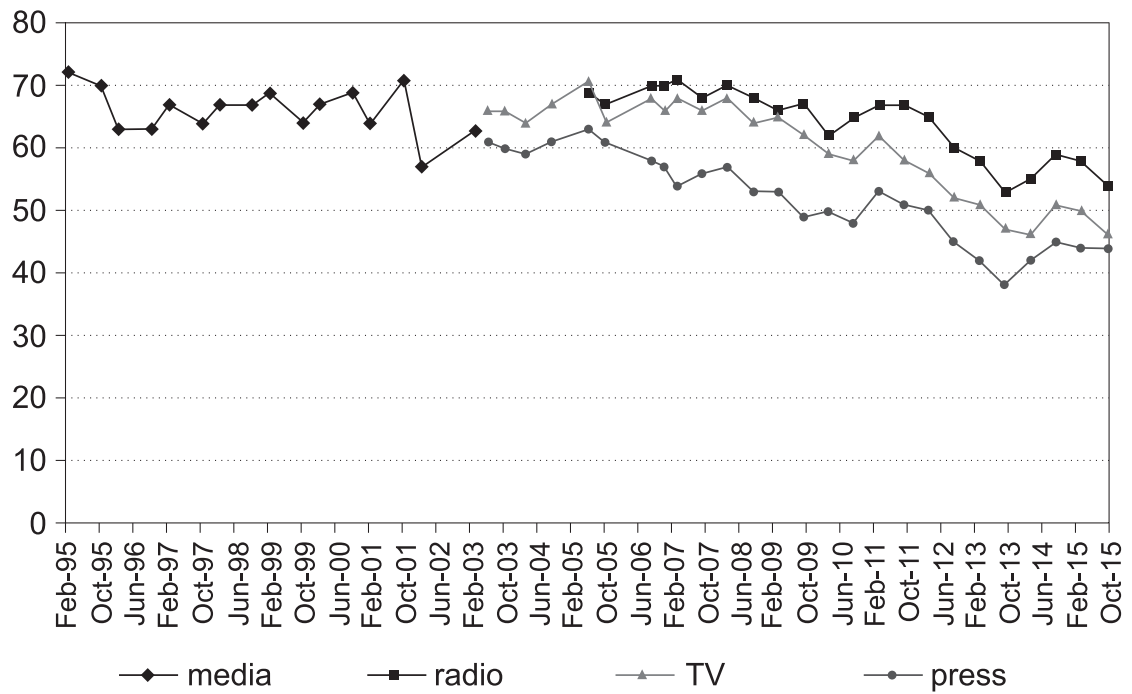

Figure 2. Trust in selected media types in the Czech Republic, 1995-2015 (in \%)

Source: CVVM (2015).

Legend: The data in the figure represent the sum of the answers I definitely trust and I rather trust as a percentage. Question wording: Please tell us, do you trust or distrust a) the press, b) TV, c) radio, $d$ ) internet? Possible answers: I definitely trust, I rather trust, I rather distrust, I definitely distrust.

Concerning the main characteristics of mistrusting audiences, according to the previous studies, trust in news organizations, journalists, and the news does not map particularly well onto socio-demographic variables (Jackob, 2010; Newman et al., 2016) and the findings are often inconsistent in this respect (Tsfati \& Ariely, 2014). This applies especially to age: while older research suggested that young people were less likely to trust media and journalists (Westley \& Severin, 1964; Carter \& Greenberg, 1965; Greenberg, 1966), newer studies from various countries come to an exactly opposite conclusion (Newman et al., 2016; Gallup, 2016).

Among the most frequently tested characteristics of mistrusting audience are values and ideological attitudes (Gunther, 1992; Hoffner \& Rehkoff, 2011; Lee 2005; Lee, 2010). A number of studies pose the question of whether, and to what extent, are journalists' political stances related to public trust in media and journalists (Dennis, 1997; Domke et al., 1999; Farnsworth \& Lichter, 2011). Previous research indicates that the stronger the group identification or the stronger the ideological stand of media consumers, the higher their mistrust in specific media as the bearers of opposing attitudes. This kind of mistrust is rising especially among individuals advocating extreme ideologically-structured mindsets - strong conservatives, socialists, and liberals are distinctively less trustful (Glynn \& Huge, 2014; Lee, 2005; Lee, 2010). This mistrust is often further incited by criticisms of the media expressed by representatives of political parties in order to spread mistrust among their supporters/followers. 
Another frequent research topic is related to the extent of consumption of specific media types and attempts to answer the question whether trust rises with the amount of media consumption (Johnson \& Kaye, 1998; Kiousis, 2001). Most studies confirm the assumption that the more audiences trust mainstream media, the more of their news coverage they consume, and vice versa (Tsfati \& Cappella, 2003). The theory of selective exposure (Sullivan, 2009; Bryant \& Davies, 2009; Smith et al., 2008) is effective here; it presumes that media consumers favor the sources that they trust as they support their political attitudes, simultaneously fueling mistrust in the media that advocate other values. The role of this selectivity has been tested and confirmed on all standardly employed sociodemographic levels. It appears that those who despise journalists and mainstream media tend to look for alternative sources. Conversely those who trust media are more likely to trust them the following day and the following year (Tsfati, 2003). Audiences who are generally mistrustful consume mainstream media less (Tsfati \& Cappella, 2003).

Based on the results of these studies, when examining the structure of mistrusting audiences, the following characteristics should be taken into consideration: a) socio-demographic variables - age, education, and social status; b) the amount of news coverage consumption; and c) values (political) orientation, especially extreme political attitudes (the far right/left).

\section{METHODOLOGY}

The following research question was posed: How has the level of public trust in Czech journalists changed in the last decade, and what is the structure and main characteristics of mistrustful audiences? As shown (Figure 2), the Czech Republic is no exception to the trend of decreasing public trust in media measured in various media systems (Gallup Poll, 2016; Eurobarometer, 2016). It was assumed that public trust in journalists would follow the decrease of public trust in media as well as the decrease in prestige of the journalistic profession in the Czech Republic, and that public trust in journalists would drop between 2004 and 2016 (hypothesis 1). Regarding the structure of mistrustful audiences, the study focused on 1) generational socio-demographic characteristics, including education and socio-economic position, 2) the amount of media consumption of respondents, and 3) value (political) orientation and its intensity. Based on the above-mentioned previous studies, the hypotheses related to the predictors of mis/trust were set in the following way:

$\mathrm{H} 2$. The mistrust of journalists will decrease with the age of the respondents.

H3. The mistrust of journalists will increase with the decrease of news media consumption.

H4. The mistrust of journalists will be the strongest with advocates of left-wing attitudes.

H5. The mistrust of journalists will be strongest with advocates of extreme political attitudes (far right/left). 
The study is based on a quantitative comparative analysis of data from two surveys designed by the authors as a part of the research project [Czech Journalists in a Comparative Perspective: Analysing the process of professionalization, professional socialization, and professional career]. The surveys were conducted with a twelve-year interval, the first data collection took place in February and March of 2004, the other in February and March of 2016. Both data sets are representative for the Czech 18+ population. The sampling was based on socio-demographic quota selection (gender, education, age, region, settlement size, socio-economic position) reflecting the structure of the Czech population. In all, 1,084 respondents were surveyed in 2004, and 1,236 were surveyed in 2016. The data were collected by social research companies according to the instructions of the authors; in both cases, the CAPI data collection strategy was used.

\section{FINDINGS}

As expected, the level of Czech public trust in journalists declined significantly between 2004 and 2016. The share of trusting respondents decreased by a third (from $47 \%$ to $29 \%$ ), and the share of mistrustful respondents increased significantly from $19 \%$ to $46 \%$. These results correspond to the above-mentioned decrease of prestige of the journalistic profession (Figure 1) and of public trust in media (Figure 2). Moreover, they are in line with previous studies affirming the increasingly skeptical attitude of the public toward journalists in the most developed western countries (e.g. Tsfati \& Peri, 2006; Gronke \& Cook, 2007; Lee, 2010; Muller, 2013; Gallup Poll, 2016).

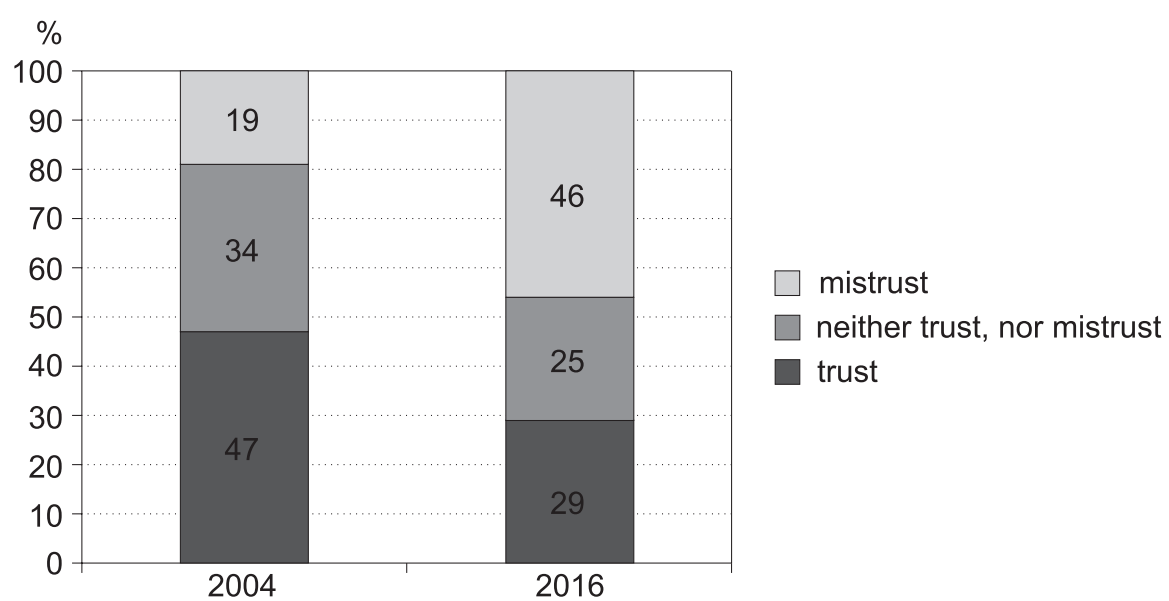

Figure 3. Public trust in Czech journalists, 2004-2016

Source: Authors.

Legend: Question wording: To what extent do you trust the representatives of these professions [journalists]? Use a seven-point scale, where 1 means definitely trust and 7 means definitely distrust. Use any number on a seven-point scale that best reflects your opinion. 


\section{MISTRUST IN JOURNALISTS AS A SIGNAL OF SOCIO-ECONOMIC DEPRIVATION OF THE YOUNGEST MEDIA CONSUMERS}

Untrustworthy media lose their audiences; commercial media also risk the loss of their advertisers to whom they sell their readers, viewers, and listeners. In other words, public trust constitutes a key condition of economic sustainability, especially of commercial media.

In this respect, this study confirms the findings of previous studies which repeatedly present a high correlation between mistrust in journalists or in media and low rates/measurements of their consumption (e.g., Tsfati \& Cappella, 2003). Table 1 shows that mistrust is most closely associated with the lowest measure of news media consumption. It is the measure which is reported by the youngest respondents, the best educated respondents, and the respondents with the highest income.

Table 1. Measure of mis/trust in journalists according to media consumption intensity (2016)

\begin{tabular}{|l|c|c|c|c|c|}
\hline & & $\begin{array}{c}\text { Definitely+ } \\
\text { rather trust }\end{array}$ & $\begin{array}{c}\text { Neither trust } \\
\text { nor mistrust }\end{array}$ & $\begin{array}{c}\text { Definitely+ } \\
\text { rather mistrust }\end{array}$ & Total \\
\hline \multirow{3}{*}{ Heavy consumer } & $\mathrm{N}$ & 101 & 94 & 109 & 304 \\
\cline { 2 - 6 } & $\%$ & 33.2 & 30.9 & 35.9 & 100 \\
\hline \multirow{3}{*}{ Middle consumer } & $\mathrm{N}$ & 153 & 125 & 219 & 497 \\
\cline { 2 - 6 } & $\%$ & 30.8 & 25.2 & 44.1 & 100 \\
\hline \multirow{3}{*}{ Light consumer } & $\mathrm{N}$ & 83 & 78 & 174 & 335 \\
\cline { 2 - 6 } & $\%$ & 24.8 & 23.3 & 51.9 & 100 \\
\hline \multirow{3}{*}{ Total } & $\mathrm{N}$ & 337 & 297 & 502 & 1136 \\
\cline { 2 - 6 } & $\%$ & 29.7 & 26.1 & 44.2 & 100 \\
\hline
\end{tabular}

Source: Authors.

Association Gamma coefficient $=0.153^{* *}$; statistically significant at the level $\alpha=0.01$.

Legend: The respondents were categorized into heavy/middle/light consumers according to their score in the index of consumption. The index was based on the level of consumption of news coverage in the daily press, TV, radio, and internet (daily $=5$ pts, $3-5$ times per week $=4$ pts, $1-2$ times per week $=3$ pts, less often $=2$ pts, exceptionally $=1 \mathrm{pt}$ ). The index ranges from 4 (the lowest possible media consumption) to 20 (the highest possible media consumption); light consumers $=4-9$ pts, middle consumers $=10-14$ pts, heavy consumers $=15-20$ pts .

Especially significant are the noticeable changes in the structure of the mistrustful in 2004 and 2016 (Tables 2 and 3). One fifth (18\%) of the mistrustful in the youngest target group in 2004 increased to more than one half. Consequently, it seems that, within the last decade, mistrustful media consumers became considerably younger. Simultaneously, they no longer belong to the formally best-educated respondents, who should exhibit a higher level of critical media literacy. On the contrary, the mistrust grew most distinctively with the consumers with the lowest formal education - from $19 \%$ to $49 \%$. This striking shift implies that journalists working for mainstream media are losing their, in the long-term view, most 
important audiences from both an economic perspective (young media consumers) and democratic participation perspective (less- educated media consumers).

Table 2. Measure of mis/trust in journalists according to age and survey year

\begin{tabular}{|c|c|c|c|c|c|c|c|}
\hline \multicolumn{2}{|c|}{} & \multicolumn{3}{|c|}{2016} & \multicolumn{3}{c|}{2004} \\
\cline { 2 - 8 } \multicolumn{2}{|c|}{} & $\begin{array}{c}\text { Definitely } \\
\text { rather trust }\end{array}$ & $\begin{array}{c}\text { Neither trust } \\
\text { nor mistrust }\end{array}$ & $\begin{array}{c}\text { Definitely }+ \\
\text { rather } \\
\text { mistrust }\end{array}$ & $\begin{array}{c}\text { Definitely }+ \\
\text { rather trust }\end{array}$ & $\begin{array}{c}\text { Neither trust } \\
\text { nor mistrust }\end{array}$ & $\begin{array}{c}\text { Definitely + } \\
\text { rather } \\
\text { mistrust }\end{array}$ \\
\hline \multirow{3}{*}{$18-29$} & $\mathrm{~N}$ & 55 & 48 & 116 & 124 & 90 & 46 \\
\cline { 2 - 8 } & $\%$ & 25.1 & 21.9 & 53.0 & 47.7 & 34.6 & 17.7 \\
\hline \multirow{3}{*}{$30-39$} & $\mathrm{~N}$ & 73 & 68 & 96 & 89 & 74 & 29 \\
\cline { 2 - 8 } & $\%$ & 30.8 & 28.7 & 40.5 & 46.4 & 38.5 & 15.1 \\
\hline \multirow{3}{*}{$40-49$} & $\mathrm{~N}$ & 51 & 56 & 109 & 112 & 77 & 47 \\
\cline { 2 - 8 } & $\%$ & 23.6 & 25.9 & 50.5 & 47.5 & 32.6 & 19.9 \\
\hline \multirow{3}{*}{$50-59$} & $\mathrm{~N}$ & 59 & 50 & 82 & 74 & 59 & 40 \\
\cline { 2 - 8 } & $\%$ & 30.9 & 26.2 & 42.9 & 42.8 & 34.1 & 23.1 \\
\hline \multirow{3}{*}{$60+$} & $\mathrm{N}$ & 111 & 91 & 159 & 115 & 69 & 39 \\
\cline { 2 - 8 } & $\%$ & 30.7 & 25.2 & 44.0 & 51.6 & 30.9 & 17.5 \\
\hline \multirow{2}{*}{ Total } & $\mathrm{N}$ & 350 & 313 & 562 & 514 & 369 & 201 \\
\cline { 2 - 8 } & $\%$ & 28.6 & 25.6 & 45.9 & 47.4 & 34.0 & 18.5 \\
\hline
\end{tabular}

Source: Authors.

Table 3. Measure of mis/trust in journalists according to education and survey year

\begin{tabular}{|c|c|c|c|c|c|c|c|}
\hline & \multicolumn{3}{|c|}{2016} & \multicolumn{3}{|c|}{2004} \\
\hline & & $\begin{array}{c}\text { Definitely } \\
+ \text { rather } \\
\text { trust }\end{array}$ & $\begin{array}{l}\text { Neither } \\
\text { trust nor } \\
\text { mistrust }\end{array}$ & $\begin{array}{l}\text { Definitely } \\
+ \text { rather } \\
\text { mistrust }\end{array}$ & $\begin{array}{c}\text { Definitely } \\
+ \text { rather } \\
\text { trust }\end{array}$ & $\begin{array}{l}\text { Neither } \\
\text { trust nor } \\
\text { mistrust }\end{array}$ & $\begin{array}{l}\text { Definitely } \\
+ \text { rather } \\
\text { mistrust }\end{array}$ \\
\hline \multirow{2}{*}{ Primary } & $\mathrm{N}$ & 44 & 41 & 80 & 60 & 40 & 23 \\
\hline & $\%$ & 26.7 & 24.8 & 48.5 & 48.8 & 32.5 & 18.7 \\
\hline \multirow{2}{*}{$\begin{array}{l}\text { Secondary } \\
\text { without the } \\
\text { school leaving } \\
\text { exam }\end{array}$} & $\mathrm{N}$ & 119 & 114 & 198 & 216 & 139 & 65 \\
\hline & $\%$ & 27.6 & 26.5 & 45.9 & 51.4 & 33.1 & 15.5 \\
\hline \multirow{2}{*}{$\begin{array}{l}\text { Secondary } \\
\text { with the school } \\
\text { leaving exam }\end{array}$} & $\mathrm{N}$ & 131 & 102 & 187 & 191 & 151 & 80 \\
\hline & $\%$ & 31.2 & 24.3 & 44.5 & 45.3 & 35.8 & 19.0 \\
\hline \multirow{2}{*}{$\begin{array}{l}\text { University } \\
\text { education }\end{array}$} & $\mathrm{N}$ & 55 & 56 & 98 & 47 & 39 & 33 \\
\hline & $\%$ & 26.3 & 26.8 & 46.9 & 39.5 & 32.8 & 27.7 \\
\hline \multirow{2}{*}{ Total } & $\mathrm{N}$ & 349 & 313 & 563 & 514 & 369 & 201 \\
\hline & $\%$ & 28.5 & 25.6 & 46.0 & 47.4 & 34.0 & 18.5 \\
\hline
\end{tabular}

Source: Authors. 
Apart from the above-stated characteristics, a higher level of mistrust is also associated with lower social position, with an example of low-income respondents who are either unemployed or students (Tables 4 and 5). This basic socio-demographic description of the mistrusting audiences shows that the journalists working for 'big media' are mistrusted by those respondents who, in one way or another, appear on the margins of society. These findings appear throughout our study and hint that mainstream media and mainstream media journalists are accepted by those who are socially and economically quite successful. The simultaneous rise of mistrust among the youngest and the least educated respondents is highly significant.

Table 4. Measure of mis/trust in journalists according to the head of household income (2016)

\begin{tabular}{|l|c|c|c|c|c|}
\hline \multicolumn{2}{|c|}{} & $\begin{array}{c}\text { Definitely }+ \\
\text { rather trust }\end{array}$ & $\begin{array}{c}\text { Neither trust } \\
\text { nor mistrust }\end{array}$ & $\begin{array}{c}\text { Definitely }+ \\
\text { rather } \\
\text { mistrust }\end{array}$ & Total \\
\hline \multirow{2}{*}{ Up to 10.000 CZK $(\sim 370 €)$} & $\mathrm{N}$ & 12 & 8 & 33 & 53 \\
\cline { 2 - 6 } & $\%$ & 22.6 & 15.1 & 62.3 & 100 \\
\hline \multirow{2}{*}{$10.001-20.000 \mathrm{CZK}(\sim 371-738 €))$} & $\mathrm{N}$ & 132 & 103 & 169 & 404 \\
\cline { 2 - 6 } & $\%$ & 32.7 & 25.5 & 41.8 & 100 \\
\hline \multirow{2}{*}{$\begin{array}{l}20.001-30.000 \mathrm{CZK}(\sim 739- \\
1.106 €)\end{array}$} & $\mathrm{N}$ & 65 & 78 & 117 & 260 \\
\hline \multirow{3}{*}{$30.001 \mathrm{CZK}$ and more $(\sim 1.107 €)$} & $\%$ & 25.0 & 30.0 & 45.0 & 100 \\
\cline { 2 - 6 } & $\mathrm{N}$ & 15 & 25 & 35 & 75 \\
\hline \multirow{2}{*}{ Total } & $\%$ & 20.0 & 33.3 & 46.7 & 100 \\
\hline & $\mathrm{N}$ & 224 & 214 & 354 & 792 \\
\cline { 2 - 6 } & $\%$ & 28.3 & 27.0 & 44.7 & 100 \\
\hline
\end{tabular}

Source: Authors.

Legend: for conversion of Czech currency to Euro we used the following exchange rate: 1 Euro $=27.40 \mathrm{CZK}$.

Table 5. Measure of mis/trust in journalists according to employment position (2016)

\begin{tabular}{|l|c|c|c|c|c|}
\hline \multicolumn{2}{|c|}{} & $\begin{array}{c}\text { Definitely }+ \\
\text { rather trust }\end{array}$ & $\begin{array}{c}\text { Neither trust nor } \\
\text { mistrust }\end{array}$ & $\begin{array}{c}\text { Definitely }+ \\
\text { rather mistrust }\end{array}$ & Total \\
\hline \multirow{3}{*}{ Employee } & $\mathrm{N}$ & 160 & 147 & 264 & 571 \\
\cline { 2 - 6 } & $\%$ & 28.0 & 25.7 & 46.2 & 100 \\
\hline \multirow{3}{*}{ Freelance } & $\mathrm{N}$ & 32 & 35 & 50 & 117 \\
\cline { 2 - 6 } & $\%$ & 27.4 & 29.9 & 42.7 & 100 \\
\hline \multirow{3}{*}{ Unemployed } & $\mathrm{N}$ & 9 & 8 & 35 & 52 \\
\cline { 2 - 6 } & $\%$ & 17.3 & 15.4 & 67.3 & 100 \\
\hline
\end{tabular}




\begin{tabular}{|l|c|c|c|c|c|}
\hline \multirow{3}{*}{ OAP } & $\mathrm{N}$ & 117 & 87 & 145 & 349 \\
\cline { 2 - 6 } & $\%$ & 33.5 & 24.9 & 41.5 & 100 \\
\hline \multirow{3}{*}{ Student } & $\mathrm{N}$ & 18 & 18 & 43 & 79 \\
\cline { 2 - 6 } & $\%$ & 22.8 & 22.8 & 54.4 & 100 \\
\hline \multirow{3}{*}{ Others } & $\mathrm{N}$ & 14 & 20 & 26 & 60 \\
\cline { 2 - 6 } & $\%$ & 23.3 & 33.3 & 43.3 & 100 \\
\hline \multirow{3}{*}{ Total } & $\mathrm{N}$ & 350 & 315 & 563 & 1228 \\
\cline { 2 - 6 } & $\%$ & 28.5 & 25.7 & 45.8 & 100 \\
\hline
\end{tabular}

Source: Authors.

Cramer's association coefficient $\mathrm{V}=0.09^{* *}$; statistically significant at the level $\alpha=0.05$.

The results show a structure of mistrust, determined by age, education, and socio-economic conditions, a structure which encloses especially the young, socially weak, and least (formally) educated media consumers, whose inferior social position increases their mistrust in mainstream media and mainstream media journalists.

\section{MISTRUST IN JOURNALISTS AS THE RESULT OF ASYMMETRY BETWEEN THE POLITICAL ORIENTATION OF JOURNALISTS AND THAT OF THE CONSUMERS OF MEDIA PRODUCTS}

The role of the value orientation or political preferences of the media and journalists, or the measure of their agreement with the preferences of potential consumers, is a well-researched topic (Dennis, 1997; Farnsworth \& Lichter, 2011; Gunther, 1992; Hoffner \& Rehkoff, 2011; Lee, 2005; Lee, 2010). As mentioned earlier, the theory of selective exposure is one of the dominant explanatory frames for this study; this theory holds that media consumers select the sources that they trust or that support their political attitudes.

Research data from the Czech Republic leads to a similar interpretation. Higher mistrust in journalists was declared by left-wing oriented respondents (Table 6), who moderately prevail in the population (as shown in Figure 4). A value asymmetry can be found in the Czech public media space - left-wing respondents prevail in the adult population; middle-right liberal ideology prevails among journalists.

Although the comparison of the newest political preferences of journalists (2016) with the data from 2004 shows that this value disproportion has been diminishing in the last decade, the stated asymmetry remains. Left-wing consumers perceive it as an expression of insufficient representation of their interests, and their mistrust in journalists is growing. It seems that while Czech journalists have been moving from right-wing to center positions in the last decade, a major part of society has been heading to the left. 
Table 6. Mis/trust in journalists according to the political orientation of respondents (2016)

\begin{tabular}{|l|c|c|c|c|}
\hline \multicolumn{2}{|c|}{} & $\begin{array}{c}\text { Definitely }+ \\
\text { rather trust }\end{array}$ & $\begin{array}{c}\text { Neither trust } \\
\text { nor mistrust }\end{array}$ & $\begin{array}{c}\text { Definitely }+ \\
\text { rather } \\
\text { mistrust }\end{array}$ \\
\hline \multirow{2}{*}{ Left-wing } & $\mathrm{N}$ & 122 & 86 & 213 \\
\cline { 2 - 5 } & $\%$ & 29.0 & 20.4 & 50.6 \\
\hline \multirow{3}{*}{ Centre } & $\mathrm{N}$ & 113 & 127 & 191 \\
\cline { 2 - 5 } & $\%$ & 26.2 & 29.5 & 44.3 \\
\hline \multirow{3}{*}{ Right-wing } & $\mathrm{N}$ & 108 & 97 & 155 \\
\cline { 2 - 5 } & $\%$ & 30.0 & 26.9 & 43.1 \\
\hline \multirow{3}{*}{ Total } & $\mathrm{N}$ & 343 & 310 & 559 \\
\cline { 2 - 5 } & $\%$ & 28.3 & 25.6 & 46.1 \\
\hline
\end{tabular}

Source: Authors.

Legend: Political orientation was measured on a seven-point scale (question wording: Terms "right" and "left" are often used in politics. Where would you place yourself on a seven-point scale?). The values 1, 2, 3 were recoded as left-wing; the values 5, 6, 7 were coded as right-wing. The center is represented by the value 4 .

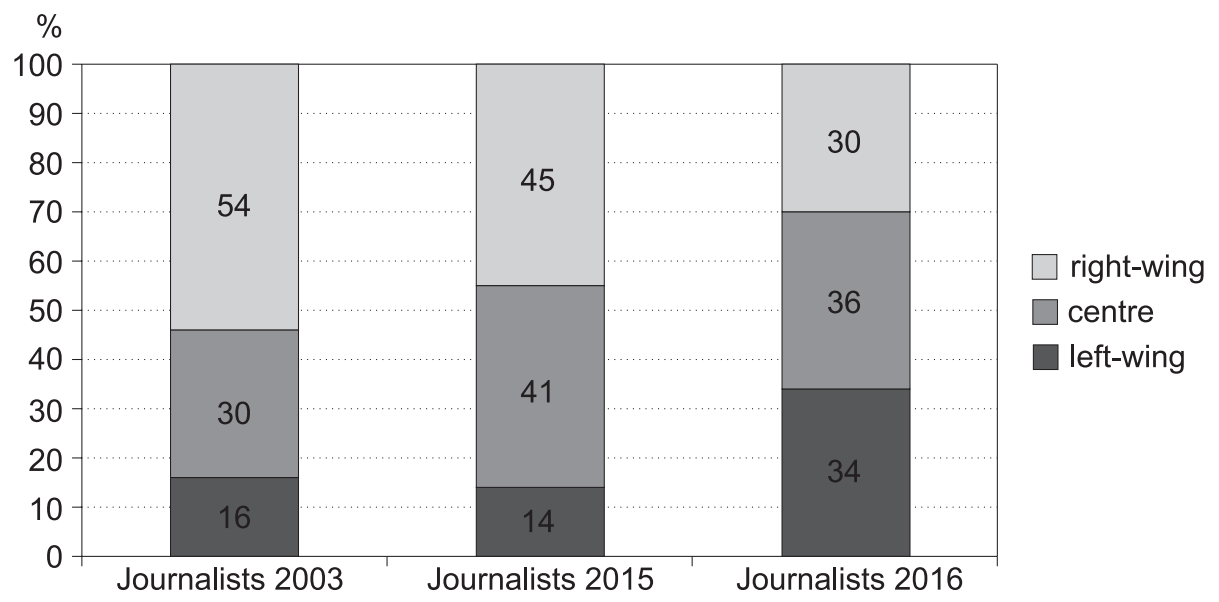

Figure 4. Self-categorization of Czech journalists on the scale "right-wing" and "left-wing"

Source: Authors.

Legend: Political orientation was measured on a seven-point scale (question wording: Terms "right" and "left" are often used in politics. Where would you place yourself on a seven-point scale?). The values 1, 2, 3 were recoded as left-wing in the figure; the values 5, 6, 7 were coded as right-wing. The center is represented by the value 4 .

In accordance with hypothesis 4 and 5, mistrust in journalists is strongest with the advocates of extreme left-wing attitudes. The more identified media consumers are with extreme positions, the more probable their increase of mistrust in the 
mainstream media (Glynn \& Huge, 2014; Lee, 2005; 2010). As Table 7 shows, the strongest mistrust was reported by extreme left-wing respondents, whereas the mistrust of extreme right-wing consumers stays below the average of the whole population. This may be a reflection of the right-wing liberal political preferences widely held by Czech journalists.

Table 7. Measure of mis/trust in journalists according to their political orientation - extreme positions (2016)

\begin{tabular}{|l|c|c|c|c|}
\hline \multicolumn{2}{|c|}{} & $\begin{array}{c}\text { Definitely }+ \\
\text { rather trust }\end{array}$ & $\begin{array}{c}\text { Neither trust nor } \\
\text { mistrust }\end{array}$ & $\begin{array}{c}\text { Definitely }+ \\
\text { rather mistrust }\end{array}$ \\
\hline \multirow{2}{*}{$\begin{array}{l}\text { Extreme left- } \\
\text { wing position }\end{array}$} & $\mathrm{N}$ & 25 & 17 & 51 \\
\cline { 2 - 5 } $\begin{array}{l}\text { Other than } \\
\text { extreme position }\end{array}$ & $\%$ & 26.9 & 18.3 & 54.8 \\
\cline { 2 - 5 } $\begin{array}{l}\text { Extreme right- } \\
\text { wing position }\end{array}$ & $\mathrm{N}$ & 297 & 268 & 475 \\
\hline \multirow{2}{*}{ Total } & $\%$ & 28.6 & 25.8 & 45.7 \\
\cline { 2 - 5 } & $\mathrm{N}$ & 21 & 25 & 32 \\
\cline { 2 - 5 } & $\%$ & 343 & 32.1 & 41.0 \\
\hline
\end{tabular}

Source: Authors.

Legend: From a seven-point scale measuring political orientation, the values 1 (left-wing position) and 7 (right-wing position) were selected as extremes.

\section{MISTRUST AS A RESULT OF A SPLIT OF THE IDEAL-TYPICAL IMAGE OF A JOURNALIST}

The deepening mistrust of journalists cannot be explained only by the value asymmetry between Czech journalists and the Czech population. It seems that this increasing mistrust is also related to broader changes in the current image of journalists and journalism, an image which is perceived by the public as too distant from their actual problems, regardless of their political preferences.

A comparison of the semantic images of Czech journalists measured by a semantic differential instrument, separated by more than a decade, does not show an unequivocally negative transformation (Table 8). Rather, there has been a shift from a fairly idealized image of a journalist to a more polarized perception. This shift is particularly towards a negative assessment - all six negatively defined attributes became stronger. The positive perception is on the decline but four out of six observed categories with a positive valence are supported by more than half of the respondents. 
Table 8. Comparison of semantic images of Czech journalists in 2004 and 2016

\begin{tabular}{|l|c|c|c|c|}
\hline & \multicolumn{2}{|c|}{2016} & \multicolumn{2}{c|}{2004} \\
\hline & $\mathrm{N}$ & $\%$ & $\mathrm{~N}$ & $\%$ \\
\hline Sensationalistic (Respectable) & 556 & $45.8(33.6)$ & & \\
\hline Corruptible (Incorruptible) & 418 & $33.9(42.0)$ & 364 & $33.6(33.6)$ \\
\hline Dependent (Independent) & 397 & $32.3(47.2)$ & 269 & $24.8(46.6)$ \\
\hline Overpaid (Underpaid) & 391 & $31.8(20.8)$ & & \\
\hline Immoral (Moral) & 335 & $27.3(53.3)$ & 194 & $17.9(46.8)$ \\
\hline Uneducated (Educated) & 318 & $26.0(53.6)$ & 52 & $4.8(80.2)$ \\
\hline Irresponsible (Responsible) & 285 & $23.2(53.5)$ & 165 & $15.2(60.5)$ \\
\hline Collaborator (Critical of the regime) & 265 & $21.8(45.0)$ & & \\
\hline Idle (Overloaded) & 254 & $20.8(36.2)$ & & \\
\hline Cowardly (Courageous) & 244 & $19.9(54.6)$ & & \\
\hline Useless (Beneficial) & 205 & $16.7(65.7)$ & 63 & $5.8(77.8)$ \\
\hline
\end{tabular}

Source: Authors.

Legend: Question wording: Which of these characteristics come to your mind when you think of the average Czech journalist? Now I read two contradictory statements. Please tell me to what extent do you think they fit the average Czech journalist. The lower the number you choose, the more you agree with the first statement, the higher the number you select, the more you agree with the other statement. Possible answers: scale 1 to 7 . The values 1-3 were recoded as agreement with the first statement, the values 5-7 were recoded as agreement with the second statement (in brackets in the Table). The percentage expresses the measure of agreement with the category in the semantic differential. The figures missing to $100 \%$ reflect an undecided stand.

Almost half of the respondents see Czech journalists as independent, which indicates that they do not consider the recent oligarchization phenomenon in Czech media and the engagement in politics of some of the media owners to be a danger to journalistic autonomy. The number of respondents who see journalists as corruptible is also stable, even though it is still rated as their second most negative attribute.

A more distinct or dynamic change can be traced in the perception of the benefit of journalists and especially in the perception of their erudition, which represented the strongest attribute of their semantic image more than a decade ago. The perception of the responsibility of journalists has also slightly declined, which is probably connected with their strongest negative attribute - low respectability, or strong sensationalism, about which almost half (46\%) of the respondents are convinced. This category was included in the semantic differential only in the latest research, therefore it is not possible to make comparisons as with some other concepts. Some of the categories correspond with the decline of both journalists' erudition and their social benefit, and with the intensifying perception of journalistic work as irresponsible. Despite this shift to a more critical observation, it can still be stated that many 
respondents do not really know what to think about journalism. They are in doubt as to whether it is an overpaid, extremely time-consuming and overburdening activity, or a well-paid cozy job.

The comparison of semantic differentials implies that the mythologized and relatively homogeneous picture of Czech journalists is falling into ruin in the eyes of the public. The ideal-typical film or fictional/literary image of journalists as 'ardent reporters' - people who do not care how many more hours they work, who live in near poverty, and who protect the public from an inhumane regime - has begun to fall apart and its outlines have blurred. Only one rather bright attribute of the journalistic image has remained: the public acknowledges that journalists need to be bold to some extent. This in turn weakens an important component in the ontological security of media consumers, who no longer reward journalists for their calculable conduct in the role of guardians of their interests. This splitting image of journalists entails the deterioration of their perceived trustworthiness.

This process of professional image splitting has several causes. One of the most important may stem from the current trend of media fragmentation and the contamination of the image of journalists by the invasion of technologically competent but amateur web journalists who have no respect for professional rules. It is a symptom of a new professional liquidity, which is disintegrating the more traditional, firmly fixed social position of journalists, who have lived their professional lives by strictly defined professional rules. The weakening of this social position and professional rules creates a situation in which journalism is increasingly open to deprofessionalization, which media consumers criticize and signify as a tabloidization, weakening professional responsibility, and the decline of the image of the journalist as a beneficial intellectual.

\section{MULTI-DIMENSIONAL STRUCTURE OF MISTRUSTFUL AUDIENCES}

To capture the structure of mistrustful public, to identify homogenous groups of mistrustful respondents, and to explore their similarities, differences and overall size, cluster analysis was chosen (Table 9), into which only mistrustful respondents were included. The given three-clustered solution indicates that mistrustful audiences come from relatively independent social groups structured by age, values, income, education, and by the measure of media consumption. This mistrust born from such a broad socio-cultural spectrum is for the authority of journalists, and thus also for news media, more dangerous than their rejection by one socio-economic or political segment of the population. 
Table 9. Clusters of mistrust: values, age, education, income and consumption attributes

\begin{tabular}{|c|c|c|c|c|}
\hline & I. Cluster & II. Cluster & III. Cluster & Total \\
\hline Left-wing & .43 & .23 & .61 & .41 \\
\hline Right-wing & .28 & .27 & .18 & .25 \\
\hline Centre & .29 & .50 & .22 & .34 \\
\hline Age 18-39 & .00 & 1.00 & .07 & .38 \\
\hline Age 40-59 & 1.00 & .00 & .00 & .35 \\
\hline Age $60+$ & .00 & .00 & .93 & .26 \\
\hline $\begin{array}{l}\text { Elementary education }+ \\
\text { training without the } \\
\text { school-leaving exam exam }\end{array}$ & .46 & .35 & .54 & .44 \\
\hline $\begin{array}{l}\text { Secondary education with } \\
\text { the school-leaving exam }\end{array}$ & .38 & .45 & .23 & .44 \\
\hline $\begin{array}{l}\text { University/college } \\
\text { education }\end{array}$ & .16 & .21 & .23 & .20 \\
\hline With a low income & .18 & .13 & .47 & .24 \\
\hline With a middle income & .59 & .56 & .41 & .53 \\
\hline With a high income & .23 & .32 & .12 & .23 \\
\hline Heavy consumers & .23 & .16 & .36 & .24 \\
\hline Average consumers & .50 & .39 & .44 & .44 \\
\hline Weak consumers & .27 & .46 & .20 & .32 \\
\hline $\begin{array}{l}\text { Relative and absolute size } \\
\text { of the cluster formed of } \\
\text { mistrustful respondents }\end{array}$ & $\begin{array}{l}34 \% \\
(138)\end{array}$ & $\begin{array}{l}47 \% \\
(187)\end{array}$ & $\begin{array}{l}19 \% \\
(78)\end{array}$ & $\begin{array}{l}100 \% \\
(403)\end{array}$ \\
\hline
\end{tabular}

Source: Authors.

Legend: K-means clustering analysis was used. The table depicts the average value of each attribute in individual clusters.

Cluster analysis clearly differentiates political groups and age groups of mistrustful media consumers. There are two left-wing clusters, the first one comprising the middle generation, the second one the oldest generation. Both cases involve respondents with the lowest education. The first cluster includes middle-income respondents, the third includes the older and the lowest-income respondents. In both cases, the respondents reported an average media consumption. The second, nonleft-wing, cluster comprises the youngest generation of middle-income respondents who are weak media consumers and validates the research finding that, with part of the audience, mistrust is associated with low media consumption.

This three-clustered solution indicates that the mistrust in journalists is high primarily among the left wing respondents. Part of the youngest generation which 
does not acknowledge left-wing values also finds journalists untrustworthy. Both of these groups report low education and social status.

None of the clusters covers the group of the propertied or the university-educated group. The measure of their mistrust is distinctively lower, which indicates that Czech journalists find their reference group in members of this higher-middle class, the affluent and educated media consumers of the middle and older generation. It is possible that they are simultaneously the individuals who have a higher share in the power distribution; if that would be the case, it might be concluded that the mistrust in journalists comes along with the mistrust in their relation to the establishment.

It seems that the outlined value asymmetry, due to the long-term inclination of the greater part of the journalistic community to right-center or liberal values, has started to 'backlash' against journalists in the form of a more markedly declared mistrust. This comes from the left-wing part of the audience who may react to the feeling of asymmetrical representation of their values and from others.

However, it can be assumed that this decline in trust cannot be related only to journalistic professional behavior. It is probable that the crisis of trust in the journalistic profession is part of a more general process of growing mistrust in public institutions as such (Norris, 1999). The increasing lack of public trust in journalists as of the significant others (Mead, 1934), the actors of public and ergo also of political life, is one of the indicators of the accelerating spiral of mistrust between the public and the political representation.

\section{DISCUSSION}

In the last two decades, the trust in media and journalists has been on the decline in most developed post-industrial societies. There is more than one reason for the current situation, and Czech journalists share some of these reasons with journalistic communities of highly developed media landscapes. This is probably due to social and socio-technological trends that affect both media market transformations and journalistic performance itself.

Secondly, apart from the outlined global socio-technological determinants of increasing mistrust, there are some local socio-economic or political determinants in each national media system. These can weaken the sense of ontological security of the population and consequently also their trust in media and media journalists. In this perspective, three time-structured types of audience mistrust can be distinguished: a) short-term, which represents only a partial disruption of trust - it is related to individual scandals and journalists' failures, b) middle-term, which exceeds several-month intervals and can be triggered by journalistic practice partaking in some adverse social processes. However, the most dangerous, from the media point of view, is c) long-term, usually gradually increasing mistrust. 
It can be assumed that Czech media and Czech media journalists are being confronted with the type of chronic mistrust that has reached the third phase. There seems to be one more general cause: a growing distance between the media and their audiences, related to the fact that a substantial number of Czech journalists have sacrificed professional rules in order to support the new regime, to which they offered not only their careers but also their values. Nevertheless, their identification with the building of a pluralistic democracy was gradually confronted with the increasing discontentment of the majority of the population, critically reacting to broken promises of transformation. There was a delayed increase of mistrust on the part of media consumers who, in the first post-1989 decade, perceived journalists as being on their side in the hope of a better future. This hopeful trust was markedly disrupted by the economic crisis, and probably also by the growing phenomenon of fake news which has affected economically languishing news media. Although the concept of fake news is not new (see e.g., Gerber and Green, 2000; Bartels, 1993), it has been gaining more traction in recent times. The declining trust in mainstream media and journalism can be both its cause and its consequence (Allcott \& Gentzkow, 2017).

Thus, the significant decline of public trust in Czech journalists can have farreaching socio-political consequences, as the disappointed audiences mistrustful of journalists may tend to be more susceptible to other sources lacking professional standards and principles of mainstream journalism. This poses an existential threat to democracy with informed citizenry as its essential element, since a confused, uninformed, misinformed, or disinformed populace is unable to make sound decisions.

The sinking trust of mainstream journalists in the Czech Republic is especially alarming in the context of a recent rise in the number of propaganda websites. It seems that a significant part of the Czech population prefers 'alternative news' sites over so-called mainstream media outlets. According to the public opinion poll by the Globsec Policy Institute (2016) conducted on the representative sample of the Czech adult population, $24 \%$ of respondents claimed to trust the 'alternative' media (e.g. ParlamentniListy.cz, AC24.cz, Prvnizpravy.cz, which according to the European Values Think Tank publish disinformation content) more than the 'traditional' media (e.g. Czech Television, Czech Radio, or the dailies Pravo or Hospodarske noviny). On the other hand, $59 \%$ of respondents claimed to trust the 'traditional' media more (and the remaining 17\% answered 'do not know'). The lack of trust in the traditional media affects the Czech Republic more than other countries from the region: in Slovakia and Hungary, about $17 \%$ of respondents trust the so-called alternative media and around $70 \%$ trust the traditional media (Globsec Policy Institute, 2016).

\section{CONCLUSIONS}

The aim of this paper was to analyze the change of public trust in Czech journalists in the time span of twelve years, and to analytically describe the structure and main 
characteristics of mistrustful audiences. As expected (Hypothesis 1), the level of public trust in journalists declined significantly between 2004 and 2016 (the percentage of a mistrustful public increased from $19 \%$ to $46 \%$ ). This means that the Czech Republic as a central European country with a post-communist media model is no exception from the trend of a rising public mistrust in media and journalists present in the most developed Euro-American countries.

The decline represents a multi-dimensionally conditioned phenomenon which has its own global macro socio-technological causes, as well as local socio-political particularities. The data support hypothesis 2 , that the mistrust decreases with the age of the respondents. In accordance with newer studies from various countries (e.g. Newman, Fletcher, Levy and Nielsen, 2016; Gallup, 2016), the analysis shows a strong mistrust with the youngest and middle generation. This reflects one of the attributes of the multi-factored structure of the public mistrust in Czech journalists. The local causes include mainly the strong left-wing nature of the mistrustful population which has grown younger in the last decade and whose formal education level has decreased.

Mistrustful audiences are characterized by the lower measure of media consumption (in accordance with hypothesis 3 ) and the left-wing political orientation (hypothesis 4 ). In line with hypothesis 5 , the mistrust gets stronger with extreme political attitudes (extreme left/right wing). In this sense, Czech consumers behave in a manner similar to some of their foreign counterparts (Glynn \& Huge, 2014; Lee, 2005; Lee, 2010).

It seems that the rather idealized image of the Czech journalist is being damaged by its professional identity split, which is determined by: a) global socio-technological trends dissolving the authoritative position of journalists as the authorized interpreters of social reality, who are being confronted with an ever-more manifold spectrum of defused amateur competitors, b) the growing distance between the media and their audiences, which is associated with a strong journalistic support of the new post-1989 regime. It appears that the value asymmetry between the leftwing part of population and the majority of Czech journalists who are partial to right-wing and liberal values begins to turn against the journalists in the form of markedly declared mistrust. This trend is especially apparent with the significant part of the left-wing audience, yet it is their form of reaction not only to the feeling their values are asymmetrically represented, but also to the unmet expectations and unfulfilled hopes that were terminated by the consequences of the economic crisis.

\section{ACKNOWLEDGEMENTS}

This work was supported by The Czech Science Foundation (GACR) under Grant Czech Journalists in a Comparative Perspective: Analysing the process of professionalization, professional socialization, and professional career (14-03028S). 


\section{REFERENCES}

Allcott, H., Gentzkow, M. (2017). Social Media and Fake News in the 2016 Election. Journal of Economic Perspectives, 31(2), pp. 211-236.

Bartels, L.M. (1993). Messages received: The political impact of media exposure. American Political Science Review, 87(2), pp. 267-285.

Bryant, J., Davies, J. (2008). Selective Exposure. In: Donsbach, W. (ed.), The International Encyclopedia of Communication. Malden, Oxford, Carlton: Blackwell Publishing.

Carter, R.F., Greenberg, B.S. (1965). Newspapers or Television: Which Do You Believe? Journalism Quarterly, 42, pp. 29-34.

CVVM. (2015). Di̊věra některým institucím veřejného života v ř́inu 2015. [Trust in Selected Public Institutions in October 2015] Retrieved May 10, 2017 from http://cvvm.soc.cas.cz/media/com form2content/documents/c1/a7447/f3/po151119.pdf.

Czech Social Science Data Archive of the Czech Institute of Sociology [Data file]. Retrieved May 10, 2017 from http://nesstar.soc.cas.cz/webview/.

Dennis, E.E. (1997). How 'liberal' are the media anyway: The continual conflict of professionalism and partisanship. Journal of Press/Politics, 2 (4), pp. 115-119.

Domke, D., Watts, M.D., Shah, D.V., Fan, D.P. (1999). The politics of conservative elites and the liberal media argument. Journal of Communication, 49(4), pp. 35-58.

Donohue, G.A., Tichenor, P.J., Olien, C.N. (1995). A guard dog perspective on the role of media. Journal of Communication, 45(2), pp. 115-132.

Eurobarometer (2016). Public Opinion: Trust in Institutions [Data file]. Retrieved May 10, 2017, from http://ec.europa.eu/COMMFrontOffice/PublicOpinion/index.cfm/Chart/index.

European Values Think Tank (2016). Recommendation for the Czech strategy against systematic disinformation campaigns of foreign powers. Kremlin Watch Policy Paper. 13.06.2016. Retrieved May 10, 2017 from http://www.europeanvalues.net/wp-content/uploads/2016/06/Recommendationfor-Czech-strategy-against-other-powers-systematic-disinformation-campaigns1.pdf.

Farnsworth, S.J., Lichter, S.R. (2011). The contemporary presidency. The return of the honeymoon: Television news coverage of new presidents, 1981-2009. Presidential Studies Quarterly, 41(3), pp. 590-603.

Gallup Poll (2016). Confidence in Mass Media. Retrieved May 10, 2017 from http://www.gallup.com/ file/poll/195575/Confidence_in_Mass_Media_160914\%20.pdf.

Gellner, E. (1990). Trust, cohesion, and the social order. In: Gambetta, D. (ed.), Trust: Making and breaking cooperative relations. Oxford, Cambridge: Basil Blackwell.

Gerber, A.S., Green, D.P. (2000). The effects of canvassing, telephone calls, and direct mail on voter turnout: A field experiment. American Political Science Review, 94(3), pp. 653-663.

Globsec Policy Institute (2016). Globsec Trends. Central Europe under the fire of propaganda: Public opinion poll analysis in the Czech Republic, Hungary and Slovakia. Retrieved May 10, 2017 from http://www.cepolicy.org/sites/cepolicy.org/files/attachments/glb_trends_en.pdf.

Glynn, C.J., Huge, M.E. (2014). Speaking in spirals: An updated meta-analysis of the spiral of silence. In: Donsbach, W., Salmon, C.T., Tsfati, Y. (eds.), The spiral of silence: New perspectives on communication and public opinion. New York, London: Routledge.

Greenberg, B.S. (1966). Media Use and Believability: Some Multiple Correlates. Journalism Quarterly, 43 , pp. 665-670.

Gronke, P., Cook, T.E. (2007). Disdaining the media: The American public's changing attitudes toward the news. Political Communication, 24(3), pp. 259-281.

Gunther, A.C. (1992). Biased press or biased public? Attitudes toward media coverage of social groups. Public Opinion Quarterly, 56(2), pp. 147-167.

Hallin, D.C., Mancini, P. (2004). Comparing media systems. Three models of media and politics. Cambridge: Cambridge University Press. 
Hoffner, C., Rehkoff, R.A. (2011). Young voters' responses to the 2004 U.S. presidential election: Social identity, perceived media influence, and behavioral outcomes. Journal of Communication, 61(4), pp. 732-757.

Jackob, N.G.E. (2010). No Alternatives? The Relationship between Perceived Media, Use of Alternative Information Sources, and General Trust in Mass Media. International Journal of Communication, 4, pp. 589-606.

Johnson, T.J., Kaye, B.K. (1998). Cruising is believing? Comparing the Internet and traditional sources on media credibility measures. Journalism and Mass Communication Quarterly, 75(2), pp. 325-245.

Kiousis, S. (2001). Public trust or mistrust? Perceptions of media credibility in the information Age. Mass Communication \& Society, 4(4), pp. 381-403.

Kovach, B., Rosenstiel, T. (2001). The elements of journalism: What news people should know and the public should expect. New York: Three Rivers Press.

Lee, T.T. (2005). The liberal media myth revisited: An examination of factors influencing media bias perception. Journal of Broadcasting and Electronic Media, 49(1), pp. 43-64.

Lee, T.T. (2010). Why they don't trust the media: An examination of factors predicting trust. American Behavioral Scientist, 54(1), pp. 8-21.

Luhmann, N. (1990). Familiarity, confidence, trust: Problems and alternatives. In: Gambetta, D. (ed.), Trust: Making and breaking cooperative relations. Oxford, Cambridge: Basil Blackwell.

Mead, G.H. (1934). Mind, self and society. Chicago: The University of Chicago Press.

Mierina, I. (2011). Political participation and development of political attitudes in post-communist countries. PhD Thesis, Riga: University of Latvia.

Mishler, W., Rose, R. (2005). What are the political consequences of trust? A test of cultural and institutional theories in Russia. Comparative Political Studies, 38(9), pp. 1050-1078.

Muller, J. (2013). Mechanisms of trust. News media in democratic and authoritarian regimes. Frankfurt am Main: Campus Verlag.

Newman, N., Fletcher, R., Levy, D.A.L., Nielsen, R.K. (2016). Reuters Institute Digital News Report 2016. Oxford: Reuters Institute for the Study of Journalism. Retrieved May 10, 2017 from http:// reutersinstitute.politics.ox.ac.uk/sites/default/files/Digital-News-Report-2016.pdf.

Norris, P. (1999). Institutional explanations for political support. In: Norris, P. (ed.), Critical citizens: Global support for democratic governance. New York: Oxford University Press.

Rose, R. (1994). Postcommunism and the problem of trust. Journal of Democracy, 5(3): pp. 18-30.

Smith, S.M., Fabrigar, L.R., Norris, M.E. (2008). Reflecting on six decades of selective exposure research: Progress, challenges, and opportunities. Social and Personality Psychology Compass, 2(1), pp. 464-493.

Sullivan, L.E. (2009). Selective Exposure. In: Sullivan, L.E. (ed.), The SAGE Glossary of the Social and Behavioral Sciences. Thousand Oaks: SAGE Publications.

Sztompka, P. (1992). Dilemmas of the great transition. Sisyphus, 2(8), pp. 9-28.

Sztompka, P. (2000). Trust: A sociological theory. Cambridge: Cambridge University Press.

Tepljuk, V.M. (1989). The Soviet Union: Professional responsibility in mass media. In: Cooper, T.W., Christians, C.G., Plude, F.F., White, R.A. (eds.), Communication ethics and global change. New York: Longman.

Tsfati, Y. (2003). Media scepticism and climate of opinion perception. International Journal of Public Opinion Research, 15(1), pp. 65-82.

Tsfati, Y., Ariely, G. (2014). Individual and Contextual Correlates of Trust in Media Across 44 Countries. Communication Research, 41(6), pp. 760-782.

Tsfati, Y., Cappella, J.N. (2003). Do people watch what they do not trust? Exploring the association between news media scepticism and exposure. Communication Research, 30(5), pp. 504-529.

Tsfati, Y., Peri, Y. (2006). Mainstream media scepticism and exposure to extra-national and sectorial news media: The case of Israel. Mass Communication and Society, 9(2), pp. 165-187.

Westley, B., Severin, W.J. (1964). Some Correlates of Media Credibility. Journalism Quarterly, 41, pp. 325-335. 